\title{
THE INFLUENCE OF MUSCULAR EXERCISE ON BLOOD SUGAR CONCENTRATIONS
}

\author{
By FLORENCE H. SMITH AND KENDRICK A. SMITH 1 \\ (From the Department of Medicine, University of Chicago, Chicago)
}

(Received for publication July 20, 1936)

The beneficial effects of exercise on certain types of diabetes mellitus have long been recognized. Occasionally a young and active diabetic, with a stable glycemia, controlled by diet and insulin, develops severe and sometimes prolonged insulin reactions following participation in strenuous sports; while other young and equally active diabetics, with an unstable glycemia, find participation in active sports a burden, accompanied by glycosuria and general malaise.

The effect of exercise on glycosuria and glycemia was deternined in twelve cases of diabetes mellitus treated with insulin; in four of diabetes mellitus treated without insulin; in three of renal glycosuria; in two of hypotension; in one patient with glycosuria of pregnancy, another with obesity, a third with epilepsy, and in three normal individuals.

\section{REVIEW OF LITERATURE}

The first direct observation on the changes in the blood sugar resulting from muscular exercise was that of Chaveau and Kaufmann quoted by Strandell (1), who demonstrated in 1886 that the blood sugar in the vein leading from the masseter muscle of a horse decreased when the horse chewed. Strandell in his historical review of the subject says that the first studies on man were made by Weiland in 1908, when he proved that the venous blood sugar concentration was considerably lower after exhausting exercise in Gärtner's ergostat than before the exercise. This was done by measuring the blood sugar concentration before the exercise was started and again after it was stopped.

Although Lichtwitz (9) in 1914 determined the effect of exercise on diabetic subjects, which will be discussed later, most of the work was done on normal subjects. Gordon, Kohn, Levine, Matton, Scriver and Whiting (2) report a study of the blood sugar concentrations in marathon runners during 1924 and 1925 . They found that the runners in bad condition at the finish of the race invariably had low blood sugars, values which could be classed as hypoglycemic. The runners trained on high carbo-

1 Data taken from a dissertation submitted to the graduate faculty in candidacy for the degree of Master of Science, Department of Medicine, University of Chicago, 1936. hydrate diets prescribed by the authors and those runners who, while running, ate glucose in some form finished in better condition than those who did not; and their blood sugars were not low enough to be classified as hypoglycemic. Best and Partridge (3) also reported hypoglycemic blood sugar levels in three of ten marathon runners following exercise. Wollmer (4) noted a decrease in the blood sugar in normal and obese persons following muscular exertion. He describes, however, immediately after the start of the work, a short but sharp rise in the blood sugar level which is followed by a decline. This is noted particularly when the work is heavy-more than thirteen kilogrammeters per second-according to his experiments. He noted no difference in the blood sugar curves in normal and obese persons. Other workers have described a rise in the blood sugar level following work. Edwards, Richards and Dill (5) found on examination of a number of football players that hyperglycemia is uncommon in exercise unless it is accompanied by emotion, as on the football field. The blood sugar reaches a peak about one-half way through the game-one varsity player had a blood sugar of $244 \mathrm{mgm}$. per $100 \mathrm{cc}$. after thirty minutes of play. Schneider (6), in examining athletes at Innsbruch, described an increase in the blood sugar following a fifty meter dash as compared to that before the race, in all of the participants who were examined. This occurred though the pre-race values varied in the different contestants between 50 and $153 \mathrm{mgm}$. per $100 \mathrm{cc}$. These differences in the blood sugar concentrations by the various authors have been considered to be due to the differences in amount as well as the intensity of the exercise. Generally, the blood sugar is lowered in long exhaustive exercises, sometimes markedly so; while the opposite effect is often found in exercise of short duration (1).

The effect of training on the blood sugar levels during exercise has also been studied. Hofmann (7) demonstrated that during exercise the blood sugar remains at a more constant level in well trained subjects than in subjects not in training. Effects from emotion were not evident in his experiments as they were in those of Edwards and Dill previously mentioned.

As has been mentioned, Lichtwitz (9) determined the effect of muscular exercise on diabetic subjects. He found that the blood sugar usually decreased but may increase with exercise, such things as severity of the diabetes and training influencing the direction of the blood sugar change. He noted particularly that in severe diabetes mellitus the values were more frequently higher than they were lower after exercise than before exercise. In one case reported (Number 19) the resting 
blood sugar value was $275 \mathrm{mgm}$. per $100 \mathrm{cc}$, and following exercise it was $377 \mathrm{mgm}$. per $100 \mathrm{cc}$. The lactic acid in this case had also risen markedly to a value of $112.5 \mathrm{mgm}$. per $100 \mathrm{cc}$. The possibility of lowering the blood sugar by exercise in diabetes mellitus has been known for some time. Joslin has pointed out that glycosuria in mild cases of diabetes mellitus may be controlled by regulating exercise taken after meals. Lawrence (10) reports lowering of the glucose concentration of the blood and the appearance of hypoglycemic reactions in two cases of diabetes mellitus following exercise. He also points out the supplementary effect of exercise in exaggerating the action of insulin. Gerl and Hofmann (11) found that the blood sugar decrease was too great to be explained by mere summation of the effect of insulin and exercise. Hamburger (12) in a report of the literature and in one case of his own showed how physical exercise (walking) permitted excellent control of the glycosuria in a child with diabetes mellitus.

Theories offered in explanation of the increase in the blood sugar following exercise are of interest here. Grott, Kowalski et al. (8) conclude that the elevation of the venous blood sugar after exercise depends upon the outflow of the sugar stored in the liver and muscles (which they call the central and peripheral reservoirs); and upon the rate of carbohydrate consumption by the tissues during work. Edwards, Richards and Dill (5) think the emotional factor is the chief cause of the blood sugar elevation following exercise. Bruusgaard (13) also mentions this as a possibility but points out that he has found hyperglycemia following exercise in which there has been no emotional excitement.

Soskin et al. (14) concluded from their experiments that there was no evidence of significant improvement in the diabetic tolerance or a decrease in the insulin requirements as a result of physical training over an extended period.

Sometime after this work was started and while it was still in progress, Richardson (15) published a study of the effect of exercise on the blood sugar in sixty-one diabetics.

$\mathrm{He}$ was able to divide his series into two groups according to the level of the fasting blood sugar. In the first group, mild diabetics with fasting blood sugars below $175 \mathrm{mgm}$. per $100 \mathrm{cc}$., exercise produced a marked lowering of the blood sugar. The second group composed of severe diabetics with fasting blood sugars over 175 mgm. per $100 \mathrm{cc}$. reacted to the same amount of exercise by an elevation of the blood sugar above that of the fasting level. $\mathrm{He}$ also found that intravenous insulin when given before a period of rest in as small quantities as 0.1 unit was without marked effect on the blood sugar, but when given immediately before a period of exercise caused a recognizable drop in blood sugar. He also describes a more marked lowering of the blood sugar following exercise after food has been taken than from the same amount of exercise taken without food.

\section{EXPERIMENTAL PROCEDURE}

The experimental procedure consisted of determining the sugar concentration of capillary blood at frequent intervals-usually every fifteen minutes-for a period of three to ten hours following the ingestion of a mixed meal or a dose of glucose while the subject was inactive; and again determining the glucose concentration of the capillary blood of the same patient at the same time intervals following an identical meal, while the subject performed a measured amount of work. Usually four or more experiments were made on each subject and each experiment was started in the morning at the subject's customary breakfast hour.

Determinations of blood sugar were made on capillary blood taken from a finger and estimated by the method of Folin and Svedberg (16). This method was modified by collecting the blood in one inch funnels on which the stems had been fused and removed. Three drops of 0.5 per cent potassium oxalate solution were air dried in the bottom of the funnels; this was sufficient to prevent clotting in as much as $0.3 \mathrm{cc}$. of blood without causing hemolysis in lesser amounts. This micro blood sugar method is accurate for concentrations ranging from 40 to $350 \mathrm{mgm}$. per 100 cc. Checks on venous blood were frequently made by macro determinations by the method of Shaffer and Hartmann (17).

The urine was analyzed for sugar qualitatively by Benedict's solution, and when necessary quantitatively by the Shaffer-Hartmann titration method, at intervals of thirty to sixty minutes throughout the experimental period. Subjects with glycosuria brought to the laboratory urine specimens collected during the preceding twentyfour hours. These were titrated for glucose which had previously been identified by fermentation tests. The urine was tested for acetone by the nitroprusside reaction.

Each case of diabetes mellitus and the case of epilepsy received a mixed meal identical with that given as part of their regular therapeutic regime in place of a glucose test meal. Those cases taking insulin received their usual dose, and care was taken to keep the time between the injection of insulin and the beginning of the meal constant. Non-diabetic subjects, with the exception of 
Cases 21 and 24, and the diabetic case Number 13 , received glucose test meals containing an equal amount of carbohydrate. The glucose was given diluted to four hundred cc. with water and flavored with lemon juice.

During the resting periods, except when blood was being taken, the subject had the freedom of the laboratory, but usually spent his time in sitting quietly reading or conversing with the workers.

All exercise was performed on a stationary bicycle, the amount of work being measured by an ergometer of the Sevringhaus type (18). The interval between the ingestion of food and the beginning of exercise was kept fairly uniform. Exercise was never begun after a meal of glucose until the blood sugar had begun to rise, to make more striking if possible, the ability of work to lower the concentration of blood sugar. It soon became evident that two subjects of normal weight for height, and of the same age, could not accomplish equal amounts of work with comfort. Such factors as previous training, musculature, and nervous reactions were observed carefully, and overambitious subjects were advised against exhaustion. No standard amount of exercise was imposed. Each subject exercised at the rate and over a period of time that was agreeable to him. After exercise, the subject usually rested in bed for fifteen to thirty minutes.

The question whether or not the blood sugars were taken while the work was in progress, or whether work was stopped even momentarily while the blood was drawn, may arise in the reader's mind. Work was stopped from two to four minutes on every subject at the time the blood was taken. The time between stopping work and drawing the blood was, however, less than one minute, the remainder of the time being spent by the subject in rest. Some justification for this method may be necessary in view of Christensen's report in 1931 (19) that the blood sugar changed rapidly back to the pre-work levels following a period of work; as do the pulse, respiratory rate, and even the basal metabolic rate. $\mathrm{He}$ said, therefore, that unless the blood was taken while work was still in progress the blood sugar values were not those of work but were " restitution values." Although this is literally true, in these experiments the blood sugar values shown on the graphs as those during work have been taken some few seconds after work was stopped. This was done for three reasons. First, with the amount of work performed by the subjects rest was necessary at fifteen minute intervals. It was decided, therefore, to take the blood as soon as possible after the subject had stepped from the stationary bicycle and walked three paces to a chair. This method simplified the drawing of the blood. Second, it was found that the difference between blood sugar levels during work, and from one to three minutes after stopping work, was not greater than the experimental error of the method. Also, if the blood sugar was descending during work the level a few minutes after work was stopped-Christensen's "restitution" value-was lower than the preceding value obtained during work; but if the blood sugar was ascending during work the level obtained a few minutes after work was stopped was higher than that level found while work was in progress. Third, if greater differences occurred than were found, it would not change the results of these experiments, since the attempt was being made to show only the relative changes in the blood sugar levels produced by work, and not necessarily the absolute values.

\section{EXPERIMENTAL RESULTS}

The experimental material is divided into five groups to simplify discussion.

Group I. Diabetes mellitus treated with insulin $A$. Well controlled (stable glycemia) ..... 3 cases

$B$. Difficultly controlled (unstable glycemia) . 4 cases

$C$. Uncontrolled (unstable glycemia) ..... 5 cases

Group II. Diabetes mellitus treated without insulin $\ldots \ldots \ldots \ldots \ldots \ldots \ldots \ldots \ldots \ldots . \ldots$ cases

Group III. Renal glycosuria ........... 3 cases

Group IV. Miscellaneous

$A$. Hypotension ................. 2 cases

$B$. Glycosuria of pregnancy $\ldots \ldots \ldots \ldots \ldots \ldots, 1$ case

$C$. Obesity . ................... 1 case

$D$. Epilepsy treated with a ketogenic diet .... 1 case

Group V. Normal subjects ............ 3 cases

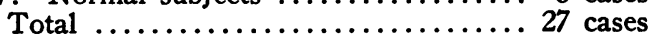

Table I gives a brief summary of the subjects' histories and the experimental procedures; more detailed information concerning diet, insulin, and total work performed will be found on the individual graphs. 
TABLE I

Summary

\begin{tabular}{|c|c|c|c|c|c|c|c|c|}
\hline $\begin{array}{c}\text { Case } \\
\text { num- } \\
\text { ber }\end{array}$ & Sex & Age & Height & Weight & $\begin{array}{l}\text { Phys- } \\
\text { ical } \\
\text { devel- } \\
\text { op- } \\
\text { ment }\end{array}$ & $\begin{array}{c}\text { Family } \\
\text { metabolic } \\
\text { history }\end{array}$ & $\begin{array}{c}\text { Aver- } \\
\text { age } \\
\text { work }\end{array}$ & $\begin{array}{c}\text { Dura- } \\
\text { tion of } \\
\text { work }\end{array}$ \\
\hline & & years & cm. & kgm. & & & $\begin{array}{c}\text { kilo- } \\
\text { gram- } \\
\text { meters } \\
\text { per } \\
\text { second }\end{array}$ & min- \\
\hline
\end{tabular}

GROUP I. DIABETES MELLITUS TREATED WITH INSULIN A. Well controlled (stable glycemia)

\begin{tabular}{|c|c|c|c|c|c|c|c|c|}
\hline $\begin{array}{l}1 \\
2 \\
3\end{array}$ & $\begin{array}{l}\mathbf{M} \\
\mathbf{F} \\
\mathbf{F}\end{array}$ & $\begin{array}{l}29 \\
40 \\
23\end{array}$ & $\begin{array}{l}173.5 \\
164.0 \\
156.5\end{array}$ & $\begin{array}{l}56.8 \\
60.9 \\
51.0\end{array}$ & $\begin{array}{l}\text { Fair } \\
\text { Fair } \\
\text { Fair }\end{array}$ & $\begin{array}{l}\text { None known } \\
\text { None known } \\
\text { Mother had } \\
\text { goiter }\end{array}$ & $\begin{array}{l}2.20 \\
2.40 \\
2.20\end{array}$ & $\begin{array}{l}75 \\
45 \\
45\end{array}$ \\
\hline
\end{tabular}

B. Difficulty controlled (unstable glycemia)

\begin{tabular}{|c|c|c|c|c|c|c|c|c|}
\hline $\begin{array}{l}4 \\
5\end{array}$ & $\begin{array}{l}\mathbf{M} \\
\mathbf{M}\end{array}$ & $\begin{array}{l}19 \\
24\end{array}$ & $\begin{array}{l}175.0 \\
179.0\end{array}$ & $\begin{array}{l}62.3 \\
63.0\end{array}$ & $\begin{array}{l}\text { Good } \\
\text { Good }\end{array}$ & $\begin{array}{l}\text { None known } \\
\text { Mother had }\end{array}$ & $\begin{array}{l}3.70 \\
2.20\end{array}$ & $\begin{array}{l}105 \\
135\end{array}$ \\
\hline 6 & $\mathbf{M}$ & 39 & 172.0 & 63.8 & Good & Glycosuria in & 1.60 & 135 \\
\hline 7 & $\mathbf{M}$ & 24 & 166.0 & 49.9 & Fair & $\begin{array}{l}\text { Glycosuria in } \\
\text { one cousin }\end{array}$ & 3.00 & 60 \\
\hline
\end{tabular}

C. Uncontrolled (unstable glycemia)

\begin{tabular}{|c|c|c|c|c|c|c|c|c|}
\hline $\begin{array}{r}8 \\
9 \\
10 \\
11\end{array}$ & $\begin{array}{l}\mathbf{F} \\
\mathbf{M} \\
\mathbf{F} \\
\mathbf{M}\end{array}$ & $\begin{array}{l}30 \\
13 \\
17 \\
25\end{array}$ & $\begin{array}{l}160.0 \\
126.0 \\
163.0 \\
171.0\end{array}$ & $\begin{array}{l}47.0 \\
28.0 \\
51.0 \\
67.5\end{array}$ & $\begin{array}{l}\text { Poor } \\
\text { Fair } \\
\text { Fair } \\
\text { Fair }\end{array}$ & $\begin{array}{l}\text { None known } \\
\text { None known } \\
\text { None known } \\
\text { Father has } \\
\text { glycosuria }\end{array}$ & $\begin{array}{l}1.10 \\
2.25 \\
1.85 \\
1.37\end{array}$ & $\begin{array}{l}75 \\
38 \\
53 \\
53\end{array}$ \\
\hline 12 & $\mathbf{F}$ & 34 & 169.0 & 61.3 & Good & Unknown & 1.53 & 25 \\
\hline
\end{tabular}

GROUP II. DIABETES MELLITUS TREATED WITHOUT INSULIN

\begin{tabular}{|c|c|c|c|c|c|c|c|c|}
\hline $\begin{array}{l}13 \\
14 \\
15 \\
16\end{array}$ & $\begin{array}{l}\mathbf{M} \\
\mathbf{M} \\
\mathbf{M} \\
\mathbf{M}\end{array}$ & $\begin{array}{l}29 \\
45 \\
47 \\
30\end{array}$ & $\begin{array}{l}178.0 \\
180.0 \\
163.0 \\
167.5\end{array}$ & $\begin{array}{r}69.4 \\
72.4 \\
101.0 \\
64.6\end{array}$ & $\begin{array}{l}\text { Good } \\
\text { Good } \\
\text { Fair } \\
\text { Fair }\end{array}$ & $\begin{array}{l}\text { None known } \\
\text { None known } \\
\text { None known } \\
\text { Mother and two } \\
\text { siblings have } \\
\text { glycosuria }\end{array}$ & $\begin{array}{l}5.00 \\
3.34 \\
3.65 \\
2.14\end{array}$ & $\begin{array}{l}60 \\
45 \\
45 \\
60\end{array}$ \\
\hline
\end{tabular}

GROUP III. RENAL GLYCOSURIA

\begin{tabular}{|c|c|c|c|c|c|c|c|c|}
\hline 17 & $\mathbf{M}$ & 47 & 1665 & 631 & $\begin{array}{l}\text { Fair } \\
\text { Fair }\end{array}$ & $\begin{array}{l}\text { Paternal grand- } \\
\text { mother had } \\
\text { glycosuria }\end{array}$ & $\begin{array}{l}3.02 \\
3.00\end{array}$ & 60 \\
\hline 19 & $\mathrm{~F}$ & 34 & 165.0 & 56.1 & Fair & $\begin{array}{l}\text { Glycosuria in } \\
\text { mother and } \\
\text { two siblings }\end{array}$ & 0.80 & 60 \\
\hline
\end{tabular}

GROUP IV. MISCELLANEOUS

A. Hypotension

\begin{tabular}{l|l|l|l|l|l|l|l|l}
\hline 20 & F & 22 & 157.5 & 47.2 & Poor & None known & 2.90 & 50 \\
21 & F & 47 & 170.5 & 75.1 & Poor & None known & 0.0 & \\
\hline
\end{tabular}

B. Glycosuria of pregnancy

\begin{tabular}{l|l|l|l|l|l|l|l|l}
\hline 22 & F & 38 & 165.0 & 75.1 & Fair & $\begin{array}{c}\text { Glycosuria in } \\
\text { mother }\end{array}$ & 2.38 & 30 \\
\hline
\end{tabular}

\section{Obesity}

\begin{tabular}{l|l|l|l|l|l|l|l|l}
\hline 23 & F & 27 & 156.0 & 89.7 & Fair & $\begin{array}{l}\text { One sibling had } \\
\text { goiter }\end{array}$ & 1.58 & 45 \\
\hline
\end{tabular}

TABLE I-Continued

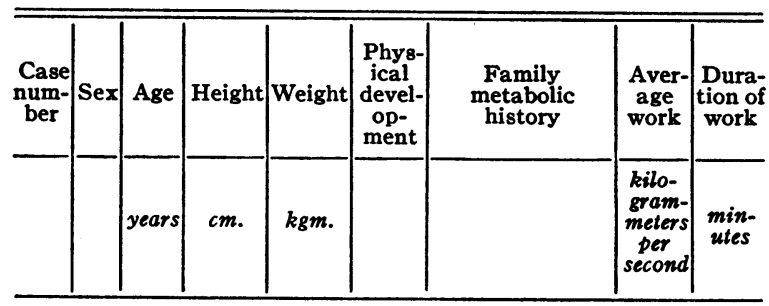

D. Epilepsy treated with a ketogenic diet

\begin{tabular}{|c|c|c|c|c|c|c|c|c|}
\hline 24 & $\mathbf{M}$ & 19 & 162.0 & 46.3 & Good & $\begin{array}{l}\text { Paternal grand- } \\
\text { mother had } \\
\text { epilepsy }\end{array}$ & 3.90 & 90 \\
\hline $\begin{array}{l}25 \\
26 \\
27\end{array}$ & $\begin{array}{l}\mathbf{M} \\
\mathbf{M} \\
\mathbf{M}\end{array}$ & $\begin{array}{l}26 \\
24 \\
29\end{array}$ & $\begin{array}{l}174.0 \\
183.0 \\
176.0\end{array}$ & $\begin{array}{l}79.0 \\
79.6 \\
76.3\end{array}$ & $\begin{array}{l}\text { Good } \\
\text { Good } \\
\text { Good }\end{array}$ & $\begin{array}{l}\text { None known } \\
\text { None known } \\
\text { None known }\end{array}$ & $\begin{array}{l}2.87 \\
3.84 \\
4.30\end{array}$ & $\begin{array}{l}75 \\
45 \\
60\end{array}$ \\
\hline
\end{tabular}

One illustrating figure will be used in each group to demonstrate the changes in the blood sugar level produced by exercise.

\section{Group I. Diabetes mellitus treated with insulin}

A. Well controlled cases (stable glycemia). The characteristics of this group are well shown by Case 1, Figure 1. They are for this group;

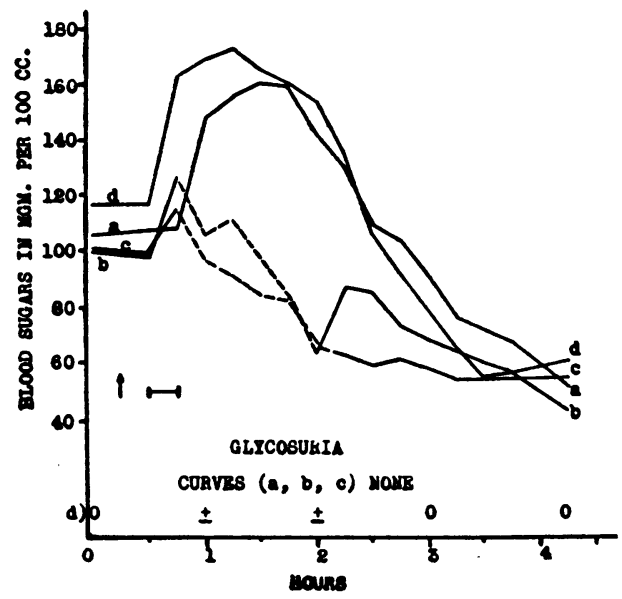

Fig. 1. Case 1.

Rest. --- Period of work. Work in kilogrammeters. Curve (b) 8,516. Curve (c) 10,954. 1 Mixed meal. Carbohydrate 48 grams, protein 20 grams, fat 64 grams, calories 848, glucose equivalent 66 grams. $\uparrow$ Insulin 15 units.

a rather low fasting blood sugar level which varies little from day to day, 86 to $150 \mathrm{mgm}$. per 100 cc.; a maximum postprandial blood sugar which is not a great deal higher than that of the 
group of normal or non-diabetic individuals studied, 156 to $197 \mathrm{mgm}$. per $100 \mathrm{cc}$; and the comparative ease with which exercise lowers the postprandial blood sugar. This reduction ranged from 12 to $90 \mathrm{mgm}$. per $100 \mathrm{cc}$. Glycosuria is not found in this group.

B. Difficultly controlled cases (unstable glycemia). These cases differ from those just described in the following respects; the greater daily variation of the fasting blood sugar level which varies from 96 to $232 \mathrm{mgm}$. per $100 \mathrm{cc}$; the higher postprandial blood sugar levels of from 158 to $256 \mathrm{mgm}$. per $100 \mathrm{cc}$; and usually the appearance of glycosuria sometime during the resting periods. Case 4, Figure 2, is a good example of this group.

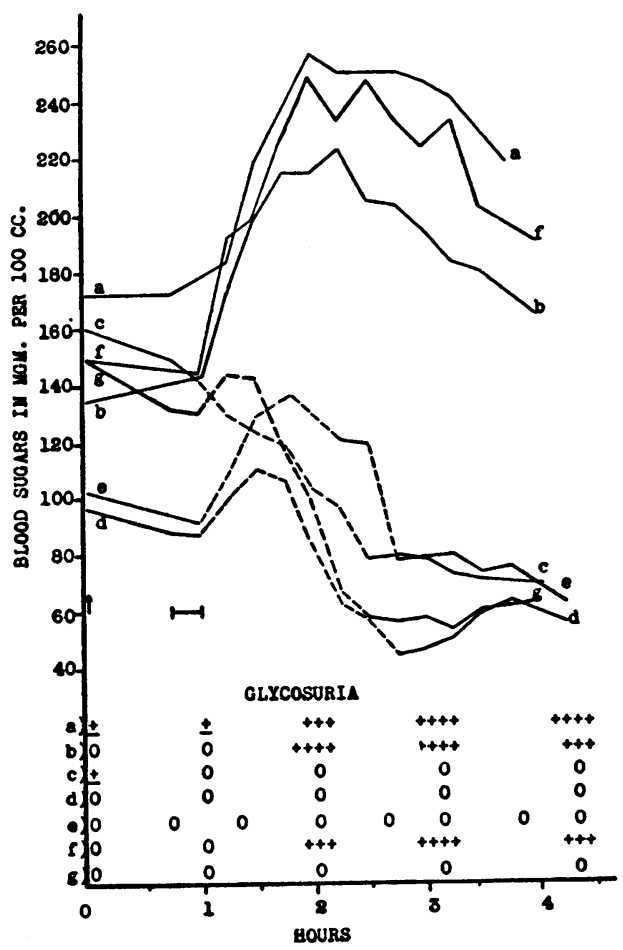

Fig. 2. Case 4.

- Rest. - - Period of work. Work in kilogrammeters. Curve (c) 21,795. Curve (d) 26,986. Curve (e) 24,676. Curve (g) 19,034. - - Mixed meal. Carbohydrate 61 grams, protein 25 grams, fat 50 grams, calories 794, glucose equivalent 82 grams. $\uparrow$ Insulin 28 units.

It is noted in this group, comprised of Cases $4,5,6$, and 7 , that exercise is very effective in lowering the postprandial blood sugar, and from the illustrative figure and the effects upon the individual subjects, such as the hypoglycemic symptoms experienced by all of the subjects in this group, the effects of exercise are more marked than in the group of well controlled subjects. The most striking difference between this and the preceding group of cases is the difference between the levels of the blood glucose at the end of the fourth hour during rest and work respectively. This difference varied from 56 to $170 \mathrm{mgm}$. per $100 \mathrm{cc}$., while in the preceding group the blood sugar levels at the end of four hours were all within $20 \mathrm{mgm}$. per $100 \mathrm{cc}$., regardless of whether. the subject had exercised or rested. Although there was this marked difference between the final blood sugar values after rest and exercise, the final values of all the studies following rest and those following exercise varied as a rule less than $30 \mathrm{mgm}$. per $100 \mathrm{cc}$.

The work in this group of cases was not excessive when compared by the subjects to the swimming, tennis, golf, or camp life in which they indulge.

C. Uncontrolled cases (unstable glycemia). Four of these cases belong to a group which might be called the acute progressive juvenile type of diabetes mellitus. Though usually found in the younger age groups this type is not necessarily limited to it. The added factor of inability to follow dietary and insulin therapy prescribed, because of financial reasons or lack of will, complicates management in at least two of these casesCases 8 and 10. Adequate control in the remaining two cases, Numbers 9 and 11, was not satisfactorily achieved during this period of study. Case 12 is not offered as an example of the progressive type of juvenile diabetes. The onset of the disease was acute, but not progressive. Emotional factors complicate management to the extent of making the case uncontrolled.

Case 8 , Figure 3 , is taken as a typical example of the response to exercise by members of this group. The characteristics of the group, as shown by the blood sugar curves, are a high fasting level of 182 to $376 \mathrm{mgm}$. per $100 \mathrm{cc}$., with an abrupt fall in the blood sugar to 56 to $238 \mathrm{mgm}$. per $100 \mathrm{cc}$. in the fourth hour; a drop which, in four of the five cases, meant a change of blood sugar level from 200 to $260 \mathrm{mgm}$. per $100 \mathrm{cc}$. in 


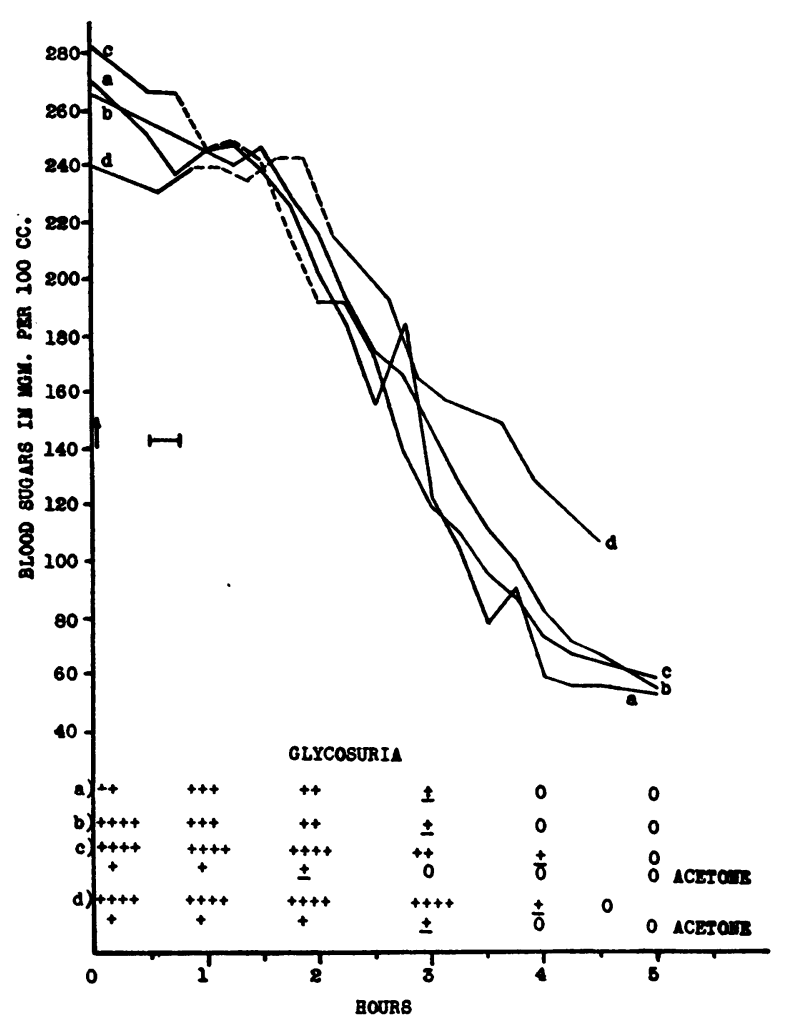

Fig. 3. CASE 8.

- Rest. - - Period of work. Work in kilogrammeters. Curve (c) 3,937. Curve (d) 6,688. ।-1 Mixed meal. Carbohydrate 28 grams, protein 14 grams, fat 50 grams, calories 618 , glucose equivalent 41 grams. $\uparrow$ Insulin 25 units.

four to five hours every morning. This rapid fall in blood sugar occurred whether or not exercise was taken. The effectiveness of the insulin is demonstrated by the character of the curve. The effect of muscular exercise is difficult to determine as will be discussed later.

\section{Group II. Diabetes mellitus treated without insulin}

Four cases are included in this group; Cases 13, 14, 15, and 16; of which Case 13, Figure 4, will be used as the illustration. These cases present a number of interesting points. First there is a small fluctuation in the daily fasting blood sugar level, which, with the exception of one case, ranged between 91 and $122 \mathrm{mgm}$. per $100 \mathrm{cc}$. Second, there is a rather close similarity of comparable curves at any one time throughout the experimental period. Third, the effectiveness of the muscular exercise on lowering the postprandial blood sugar is very similar to that found in the normal subjects. The above three characteristics are all much like those found in normal subjects under similar conditions. A fourth characteristic, demonstrated in this study only by Case 13, is the higher postprandial rise following the second meal of the day; a finding noted in diabetes mellitus and frequently utilized to diagnose mild cases which give a fairly normal glucose tolerance test.

The mixed meals fed these subjects, with the exception of Case 13, contained one gram of carbohydrate per kilogram of standard body weight. This represents approximately double the usual intake for each subject at the breakfast meal. The plan was adapted to deliberately provoke a hyperglycemia in the resting blood sugar curves as a control for the demonstration.

\section{Group III. Renal glycosuria}

Three complicated cases of renal glycosuria are included in this group. The complications are, hypertension, peptic ulcers, and pregnancy, for Cases 17, 18, and 19, respectively. Case 17, Figure 5 , is used as the illustrative case. The only effect of the hypertension on this study was to limit to some degree the amount and speed of exercise that it seemed advisable to permit. These cases react to exercise for the most part as do normal individuals. The fasting blood sugar level is within the normal limits and fluctuates only little, apparently even less than the daily fluctuation found in the normal subjects by Holt and Greischeimer (20). Also the blood sugar curve is back at the fasting level in less than two hours, it goes through a hypoglycemic phase, and, in Cases 17 and 18, glycosuria appears only in the postprandial periods at levels of 140 to 160 mgm. per $100 \mathrm{cc}$., which is below the normal renal threshold. This type of response permits a diagnosis of a cyclic renal glycosuria according to the classification of Holst (21). Case 19 demonstrated the effect of insulin on renal glycosuria of a constant nature. The effect of exercise on this case is also very similar to that of the normal individual. The blood sugar was lowered very little since only a small amount of work was done.

These three cases are of particular interest 


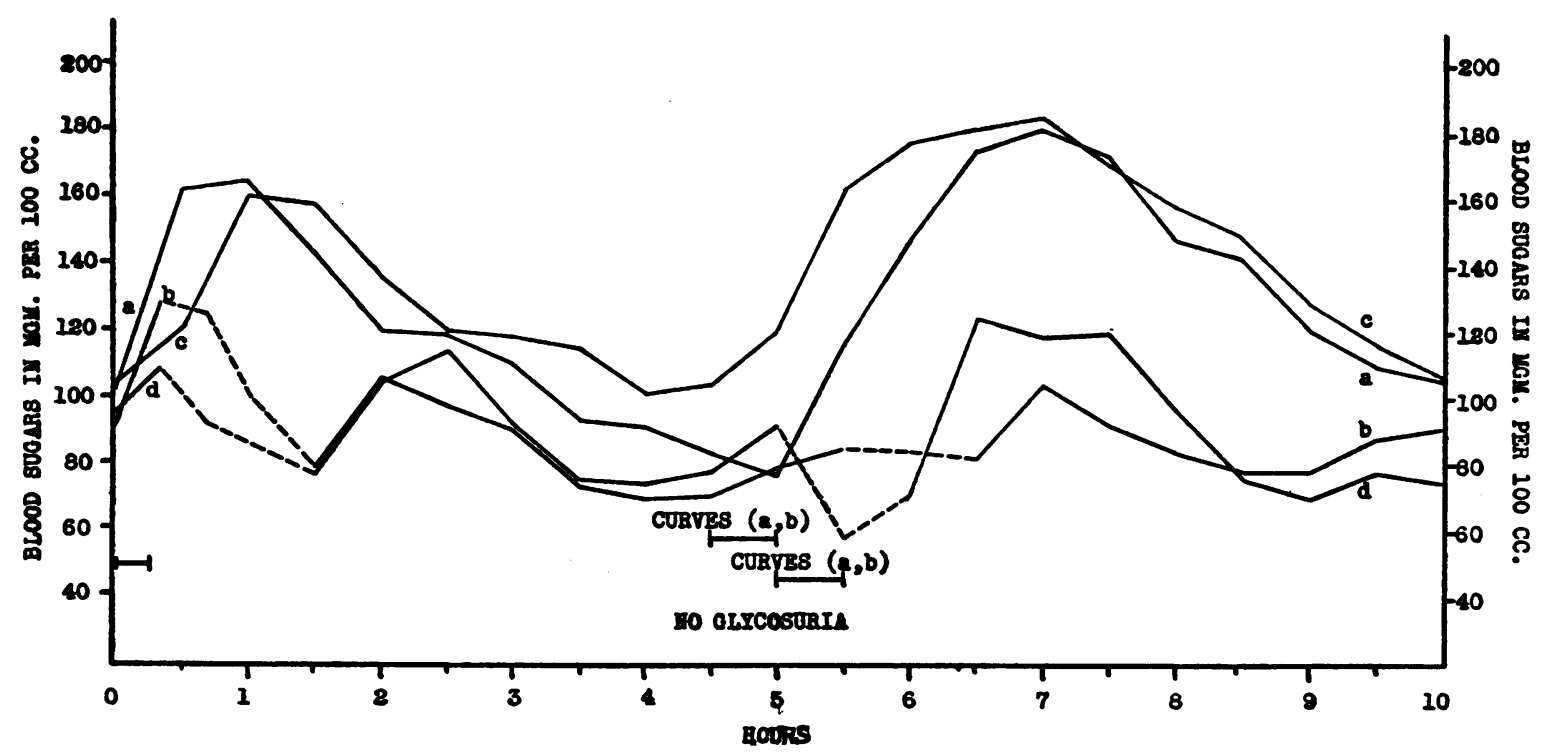

Fig. 4. CASE 13.

Rest. - - Period of work. Work in kilogrammeters.

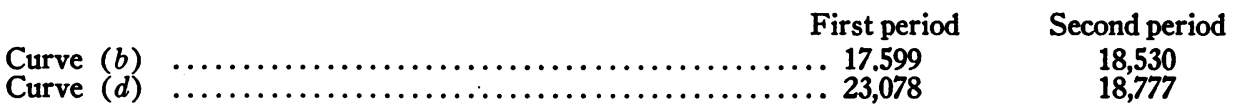
64 grams.

- Mixed meal. Carbohydrate 50 grams, protein 17 grams, fat 39 grams, calories 619, glucose equivalent

from the standpoint of a differential diagnosis between renal glycosuria and diabetes mellitus and are published elsewhere in more detail (24).

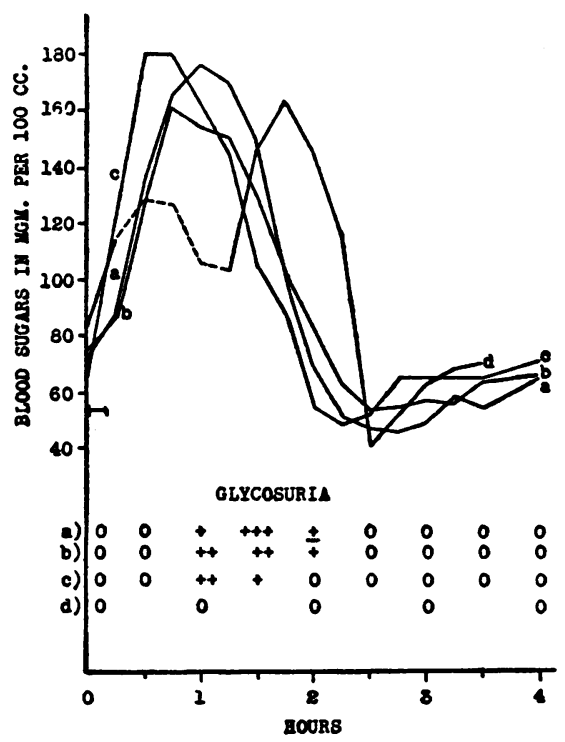

Fig. 5. CASE 17.

Rest. --- Period of work. Work in kilogrammeters. Curve $(d)$ 10,850. $|-|$ Glucose test meal 70 grams.
Group IV. Miscellaneous cases

$A$. Hypotension. The two cases in this group, Cases 20 and 21, were referred to the Nutrition Laboratory for blood sugar analysis because of symptoms suggestive of hypoglycemia; that is, weakness, inability to work, dizziness, and fainting, all relieved by the ingestion of food.

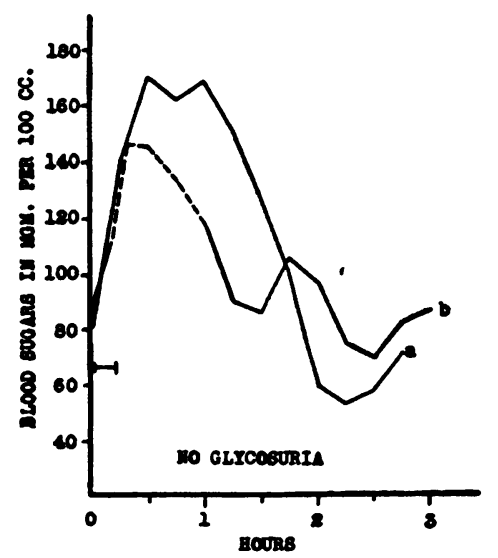

FIg. 6. CASE 20.

Rest. - - Period of work. Work in kilogrammeters. Curve (b) 8,683 . 50 grams. 
With the subject (Case 20) in a resting state following the ingestion of a glucose test meal the blood sugar course followed a normal curve for one hour, Figure 6 . At this point an abrupt drop occurred at a rate and to a level which frequently causes diabetic subjects to complain of insulin reactions. She complained of her usual symptoms of weakness, dizziness, and faintness with hunger at the time the blood sugar level was within the hypoglycemic range, 50 to $70 \mathrm{mgm}$. per $100 \mathrm{cc}$. When the glucose test meal was followed by exercise (Curve $b$ ) the absorption of the glucose appeared to be delayed as demonstrated by the second peak of the curve. During this experiment, the glucose content of the blood did not reach a hypoglycemic level, and there was no complaint of the symptoms of weakness, dizziness, etc. Insufficient exercise to be measured either by the ergometer or fall in the blood sugar level was done in Case 21 for purposes of comparison.

Simultaneous occurrence of hypoglycemic blood sugar levels and the complaints of weakness, dizziness and faintness relieved by food, suggest a diagnosis of hypoglycemia of unknown etiology in these two cases.

B. Glycosuria of pregnancy. This case, Number 22, was seen in the seventh month of her seventh pregnancy at which time a glucose tolerance test by macro blood sugar methods showed a typically diabetic type of curve. Nine and onehalf months after glycosuria was discovered the course of the blood glucose following food ingestion was followed during resting and working conditions. Both curves, Figure 7, show a normal fasting blood sugar, and although the postprandial peak is higher than those found in normal subjects, $192 \mathrm{mgm}$. per $100 \mathrm{cc}$., this tolerance test was made while the subject was still restricting her diet. The rapidity with which the blood sugar returns to the fasting level is not characteristic of diabetes mellitus. The urine remained sugar-free. The effect of work is marked and is similar to its effects on the curves of normal subjects.

C. Obesity. Case 23, Figure 8, has been approximately fifty per cent overweight for the past seven years. She was selected for these experiments because of characteristics of " endogenous"

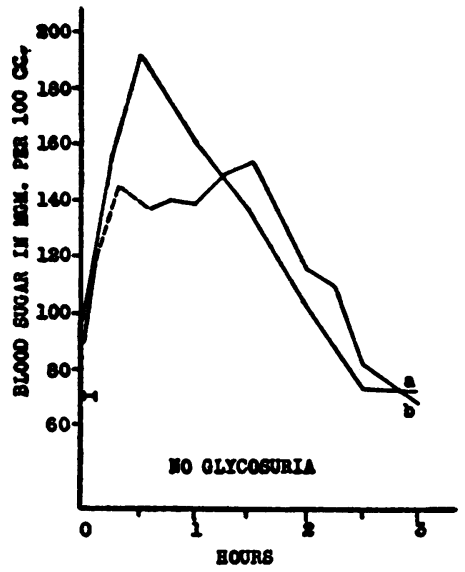

Fig. 7. Case 22.

Rest. - - Period of Work. Work in kilogrammeters. Curve (b) 4,274. - Glucose test meal 60 grams.

obesity. ${ }^{2}$ Reduction has been persistently attempted but with little permanent success. At the time these tests were made the subject had been on a liberal unrestricted diet for several months.

The blood sugar findings following the ingestion of glucose are problematic, and will be taken up in the discussion.

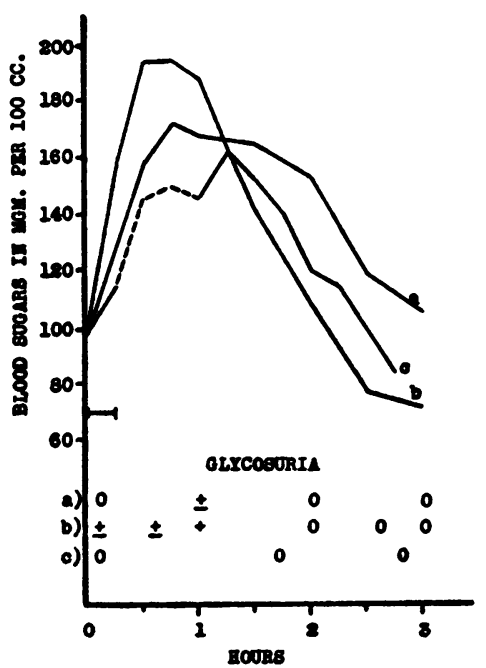

FIG. 8. CASE 23.

Rest. - - Period of work. Work in kilogrammeters. Curve (c) 4,264. 57 grams.

2 "Endogenous" obesity is used to denote those few patients resistant to weight loss by the usual methods. No other deductions as to the nature of the disturbance are inferred. 
D. Epilepsy on a ketogenic diet. Case 24 is interesting not only from the standpoint of the effect of exercise on the blood sugar values, but also because of the excellent physical condition of this subject who has been on a ketogenic diet for nine years. These experiments on the blood sugars were carried out to determine the blood sugar characteristics under conditions of work and rest, of a patient with an extremely low carbohydrate intake (Figure 9). The three experiments, one rest curve and two curves with exercise, which resemble fasting blood sugar curves, were determined following the ingestion of the patient's usual breakfast containing seven grams of preformed carbohydrate and 15 grams of available glucose.

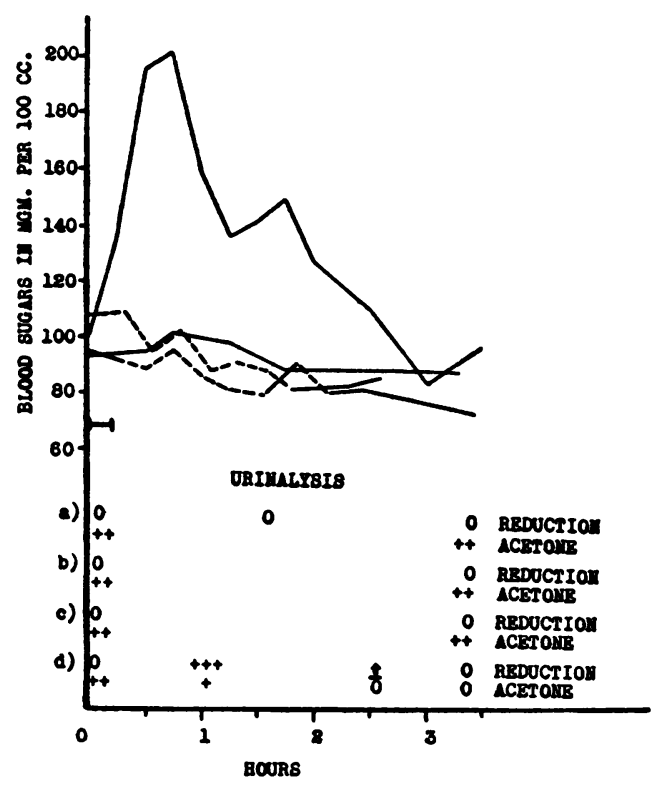

Fig. 9. CASE 24.

Rest. - - Period of work. Work in kilogrammeters. Curve (b) 19,456. Curve (c) 25,254. -1 Mixed meal, Curves $a, b, c$. Carbohydrate 7 grams, protein 10 grams, fat 37 grams, calories 431, glucose equivalent 15 grams. |- Glucose test meal 64 grams, Curve $d$.

\section{Group V. Normal subjects}

This group is composed of three adult males, one a physician and the other two students. Cases 25 and 26 , the two students, ate mixed meals for all of the blood sugar determinations made, while the blood sugar studies on Case 27 were made following the ingestion of glucose. The subjects,
Cases 25 and 26, had been on known diets of carbohydrate 250 grams, protein 75 grams, and fat 100 grams for three days previous to the experiments.

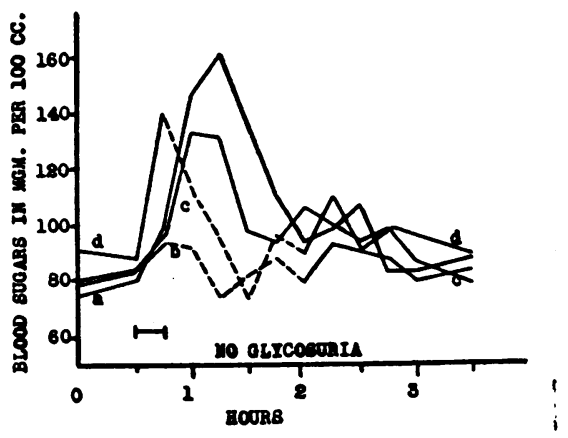

Fig. 10. Case 25.

Rest. - - Period of work. Work in kilogrammeters. Curve (b) 12,360. Curve (d) 13,423. - Mixed meal. Carbohydrate 98 grams, protein 22 grams, fat 33 grams, calories 777, glucose equivalent 112 grams.

The characteristics of the normal blood sugar curve need not be outlined here but the reader is referred to Case 25, Figure 10.

\section{DISCUSSION}

Muscular exercise affects the postprandial blood sugar in the case of well controlled diabetes mellitus, with or without the use of insulin, in a manner similar to its effect on the non-diabetic individual. It is well known that mild types of diabetes mellitus are benefited by exercise. The cases of mild or well controlled diabetes presented in this paper differ from the normal subjects mainly in the greater elevation of the blood sugar after meals. Carbohydrate metabolism is regulated well enough to control the fasting blood sugar level.

Some difference in the general characteristics of the blood sugar curves is seen in the various cases grouped for discussion under mild diabetes mellitus treated without insulin (Cases 13, 14, 15, and 16), and well controlled cases under insulin management (Cases 1, 2, and 3). The three controlled cases on insulin therapy on the whole show less variation in the blood sugar levels than the four cases not taking insulin. The fasting values are, with the exception of Case 15, not abnormally high; and two of the four cases, Num- 
bers 13 and 14 treated without insulin do not have high postprandial blood sugars. Two cases, Numbers 15 and 16, who showed glycosuria, were given diets at the time of the experiments to produce glycosuria, as has been mentioned, and do not on their usual regime have glycosuria. With the approximately normal blood sugars found in this group of well controlled diabetics it is not surprising that they should react to exercise as do normal subjects.

The effect of muscular exercise in the irregularly controlled diabetic individual appears to be more marked than in the well controlled case when judged by the difference between the level of the postprandial blood sugar during rest and immediately following exercise. The irregularly controlled cases of diabetes (Cases 4, 5, 6, and 7 ), dependent upon insulin, have a correspondingly greater variation in blood sugar levels. In all of the cases placed in this group the spontaneous adjustment of the blood sugar level during or after exercise, which seems to take place in the milder cases, is lacking. This is shown by the wide variation in the blood sugar levels at the end of the period of exercise when compared to the rest curve for the same time interval. As Lawrence (10) suggests the exercise seems to augment the effect of the insulin to a greater degree than would be expected merely from a summation of effects of insulin and exercise. Although the amount of work performed by the mild diabetics and the irregularly controlled severe diabetics may be comparable, the blood sugar levels vary widely. The body mechanism for regulation of the blood sugar seems in the case of the mild diabetics to be able to adjust itself to the effect of the exercise much better than it does in the non-diabetic individual. From an examination of the blood sugar curves, this regulating mechanism does not seem to exert its effect in the more severe cases of diabetes. This difference makes these cases more difficult to control without glycosuria or insulin shock, and especially so with a generous carbohydrate intake. The finding of a constant and marked effect from muscular work suggests that regular exercise performed at prescribed intervals might simplify the problem of insulin adjustment.

The third group, the uncontrolled cases of dia- betes (Cases $8,9,10,11$, and 12), are probably uncontrolled because of improper spacing of the insulin dosage throughout the twenty-four hours. Because of the great changes in the blood sugar levels over rather short periods, these cases feel miserable much of the time, and even though hypoglycemia is absent, may complain of symptoms from the sudden shifts in blood sugar levels rather than the absolute values. In several of the subjects in this study, Cases 8,10 , and 11 , particularly, we have been unable to differentiate between the symptoms resulting from true hypoglycemia and those resulting from a relative hypoglycemia following sudden changes in the blood sugar. Reactions which have taken place at blood sugar levels of $120 \mathrm{mgm}$. per $100 \mathrm{cc}$. are relieved promptly by administration of glucose in some form, as are those reactions which occur at blood sugar levels below $50 \mathrm{mgm}$. per $100 \mathrm{cc}$.

The effect of muscular exercise is difficult to determine because the drop in the blood sugar level from the insulin alone is such that the intake of food produces no postprandial rise in the blood sugar curve, and the amount of work that these patients were able to accomplish was small compared to the performances of the subjects in the. other groups. Had these individuals been able to perform more work, the appearance of the resting blood sugar curves makes it improbable that the levels could be changed more rapidly by the aid of exercise than it was by insulin alone.

The fall in the blood sugar at rest is particularly noticeable because of the high fasting level, and is probably due to the intake of a large quantity of insulin within a short period of time. In well or even irregularly controlled cases the administration of equally large doses of insulin is not accompanied by this rapid fall in the blood sugar. The explanation of this may also lie in the fact that these latter cases have better control of this blood sugar regulating mechanism by reason of their having some more available endogenous insulin than the uncontrolled cases. They may be able, because of this endogenous insulin, to control to some degree the fluctuations of the blood sugar and thus to hold them more nearly within normal limits, but when exercise is added to the ordinary strain upon this mechanism, large fluctuations in the blood sugar result. In these 
cases which are irregularly controlled there may be sufficient endogenous insulin together with the exogenous insulin to control blood sugar fluctuations unless some additional factor, such as strenuous exercise, is present to nullify the effects of the body regulation of carbohydrate metabolism. The recent work of Soskin et al. suggests, among other things, that liver dysfunction in the storage of glycogen may account for the marked fall in the blood sugar at rest since he has shown that a changing amount of insulin in the blood stream is not necessary for a normal glucose tolerance, but that a normal liver is necessary (22).

The effect of muscular exercise on the blood sugar of the cases of renal glycosuria, hypotension, glycosuria of pregnancy, and obesity is similar to that found in the normal individuals performing similar amounts of work. This is to be expected since there is no known metabolic disturbance in these conditions which should affect the blood sugar levels during rest and work.

The response to exercise in the case of obesity (Case 23, Figure 8) is similar to that of normal individuals; the other blood sugar changes are not typical in every respect of a non-diabetic. Curve $a$ remains high for a longer time than is usual, while Curve $b$ has an elevation higher than normal with resulting glycosuria. On the other hand, the return to the fasting level is rather prompt, and the curve with exercise shows some lowering of the blood sugar during work. Hard physical work, however, was extremely difficult for this subject and as a result the work accomplished was slight compared to that done by the other subjects in this study. One might expect, considering Wollmer's (4) findings that the blood sugar of obese subjects would react to exercise as does that of normal subjects.

The epileptic subject, Case 24, Figure 9, is introduced as an illustration of the effect of exercise on the blood sugar concentration of a nondiabetic subject on a low carbohydrate (ketogenic) food mixture. Practically no fluctuation was noted in the resting curve, in fact it appears to be the curve of a fasting person. It is not surprising that the small amount of glucose-fifteen grams-does not produce a noticeable rise, and that the effect of exercise on the blood sugar curve is negligible. Bergmark (23) has shown that as little as six and a quarter grams of glucose produces a definite elevation of the blood sugar curve during rest; and work in this laboratory confirms these observations. Our findings are not contrary to the results of his experiments as the glucose in our diet was derived from a mixed meal of high fat content which may lower the rate of absorption of carbohydrate. The work performed by this subject when compared to the work performed by the other subjects in these experiments seems more than ample to produce a leveling of any blood sugar peak which might occur following the ingestion of a mixed meal. In this case as in that of other normal subjects it has been found difficult to lower the blood sugar by work to a point greatly below the fasting level. Only the most strenuous exercise, marathon running and the like, is able to lower the blood sugar in the normal individual much below the fasting level and to deplete the glycogen stores to a point that results in hypoglycemia (2). Though this case, Number 24 , has been on a diet containing less than seventeen grams of carbohydrate for the past nine years, it is evident that his glycogen stores must be sufficiently great to prevent lowering of the blood sugar from work.

The results obtained in the three normal or healthy subjects examined were consistent in every case. It was possible to abolish the postprandial rise in the blood sugar by partaking of sufficient exercise following the meal. The blood sugar course of Case 25, Figure 10, at rest following a mixed meal, shows more variation, perhaps, than one would expect to find; but this is explained by noting that the subject had been indisposed and had eaten very little the day before Curve $a$ was made. The maximum elevation of the other three curves compares favorably with those of Cases 26 who ate mixed meals. As in the other groups, when the blood sugar rises rapidly, the removal of glucose from the blood is more marked following exercise than that found in the curves without exercise.

\section{SUMMARY AND CONCLUSIONS}

1. This paper reports the observations made on the effect of muscular exercise on the blood sugar of twenty-seven subjects. Twelve had diabetes mellitus treated with insulin; four diabetes mellitus treated without insulin; three renal gly- 
cosuria, one of which was on insulin therapy; two hypotension; and one each glycosuria of pregnancy, obesity, and epilepsy; while three were normal individuals.

2. Exercise of sufficient intensity and duration will lower the postprandial blood sugar in controlled diabetes mellitus treated with or without insulin, in renal glycosuria, in hypotension, in obesity and in normal subjects.

3. Exercise in the uncontrolled diabetic, in the amounts performed in these experiments, does not have a noticeable effect in lowering the postprandial blood sugar.

4. Exercise seems to have the greatest effect in lowering the postprandial blood sugar in the irregularly controlled diabetic, when measured by the difference in the resting and exercising blood sugar levels at the end of exercise, and by the resulting clinical symptoms at this time.

5. Exercise of the intensity performed in these experiments is not sufficient to lower the blood sugar below normal fasting levels in non-diabetics.

The authors wish to express their appreciation to Dr. Louis Leiter for his many helpful suggestions throughout the study.

\section{BIBLIOGRAPHY}

1. Strandell, B., On the influence of exercise on the blood sugar, especially in connection with glucose ingestion. Acta med. Scandinav., 1934, Supp. 55, 1.

2. Gordon, B., Kohn, L. A., Levine, S. A., Matton, M., Scriver, W. de M., and Whiting, W. B., Sugar content of the blood in runners following a marathon race with especial reference to the prevention of hypoglycemia: further observations. J. A. M. A., 1925, 85, 508.

3. Best, C. H., and Partridge, R. C., Observations on Olympic athletes. Proc. Roy. Soc. London, s. B, 1929, 105, 323.

4. Wollmer, M., Blutzuckerspiegel und Muskelarbeit bei Gesunden und Fettsuchtigen. Deutsches Arch. f. klin. Med., 1931, 170, 122.

5. Edwards, H. T., Richards, T. K., and Dill, D. B., Blood sugar, urine sugar, and urine protein in exercise. Am. J. Physiol., 1931, 98, 352.

6. Schneider, Blutzuckerbefunde vor und nach dem 50 km-Lauf. Wien. klin. Wchnschr., 1933, 46, 1448.

7. Hofmann, A., Uber den einfluss des trainings auf den ablauf der arbeitsblutzuckerkurve des stoffwechselgesunden menchen. Klin. Wchnschr., 1928, 7, 2043.

8. Grott, J. V., Kowalski, F., and others, Recherches sur la régulation de la glycémie sous l'influence de l'effort. Sang, 1931, 5, 405.

9. Lichtwitz, L., Ueber den Einfluss der Muskelarbeit auf den Gehalt des Blutes an Zucker und Milchsäure. Berl. klin. Wchnschr., 1914, 51, 1018.

10. Lawrence, R. D., The effect of exercise on insulin action in diabetes. Brit. M. J., 1926, 1, 648.

11. Gerl, A., and Hofmann, A., Uber die durch muskelarbeit hervorgerufene steigerung der insulinwirkung auf den blutzuckergehalt beim normalen und gestörten kohlenhydratstoffwechsel und ihre praktische und theoretische bedeutung. Klin. Wchnschr., 1928, 7, 1468.

12. Hamburger, F., Muskelarbeit in der Behandlung des kindlichen Diabetes. München. Med. Wchnschr., 1929, 76, 1329.

13. Bruusgaard, C., Blodsukkerets forhold ved legemsanstrengelser. Norsk mag. f. laegevidensk., 1929, 90, 778.

14. Soskin, S., Strouse, S., Molander, C. O., Vidgoff, B., and Henner, R. I., Value of muscular exercise in the treatment of diabetes mellitus. J. A. M. A., 1934, 103, 1767.

15. Richardson, R., Factors determining the effect of exercise on blood sugar in the diabetic. J. Clin. Invest., 1934, 13, 949.

16. Folin, O., and Svedberg, A., Micro methods for the determination of nonprotein nitrogen, urea, uric acid, and sugar in unlaked blood. J. Biol. Chem., 1930, 88, 85.

17. Shaffer, P. A., and Hartmann, A. F., The iodometric determination of copper and its use in sugar analysis. II. Methods for the determination of reducing sugars in blood, urine, milk and other solutions. J. Biol. Chem., 1921, 45, 365.

18. Sevringhaus, E. L., Human energy metabolism. I. A simple bicycle ergometer. Am. J. Physiol., 1927, 80, 347.

19. Christensen, E. H., Beitrage zur Physiologie schwerer körperlicher Arbeit. I. Der Blutzucker während und nach körperlicher Arbeit. Arbeitsphysiol., 1931, 4, 128.

20. Holt, G. W., and Greischeimer, E. M., Individual variations in fasting blood sugars. Proc. Soc. Exper. Biol. and Med., 1931, 28, 764.

21. Holst, J. E., Investigations into benign glycosuria and diabetes mellitus. Acta med. Scandinav., 1925-26, $63,47$.

22. Soskin, S., Allweiss, M.D., and Cohn, D. J., Influence of the pancreas and the liver upon the dextrose tolerance curve. Am. J. Physiol., 1934, 109, 155.

23. Bergmark, G., Finnes det någon renal diabetes $i$ klinisk mening? Upsala läkaref. förh. Ny följd., 1915, 21, 161.

24. Smith, F. H., and Smith, K. A., The differentiation of nomoglycemic glycosuria from other benign glycosurias and diabetes mellitus. Arch. Int. Med. (In press.) 